Journal of Epidemiology and Public Health (2017), 2(1): 32-44

https://doi.org/10.26911/jepublichealth.2017.02.01.04

\title{
Effect of Biopsychosocial Factors and Environmental Sanitation on Nutritional Status of Children Under Five Years Old in Nganjuk District
}

\author{
Wiwen Indita'), Harsono Salimo²), Endang Sutisna Sulaeman ${ }^{3)}$ \\ ${ }^{1)}$ Masters Program in Public Health, Sebelas Maret University \\ ${ }^{2)}$ Department of Pediatrics, Dr. Moewardi Hospital \\ 3) Faculty of Medicine, Sebelas Maret University
}

\begin{abstract}
Background: One of the important public health issues in Indonesia is nutritional status, particularly in children under five years old. Lack of maternal awareness of dietary intake for their children may affect growth and development. This study aimed to investigate the effect of biopsychosocial factors and environmental sanitation on nutritional status of childrens in Nganjuk District.

Subject dan Method: This was an analytic observational study using cross-sectional design. The study was conducted at Loceret Community Health Center, Nganjuk District, East Java, from March to April 2017. A sample of 136 children under five years old were selected for this study by fixed exposure sampling. The variable dependent was nutritional status measured in weight for age. The independent variables were dietary intake, history of infection disease, maternal stress, maternal education, family income, and environmental sanitation. The data were collected by anthropometry, medical record, and questionnaire. The data were analyzed with path analysis.

Results: Weight for age of children under five was affected by dietary intake $(b=0.23, S E<0.001$, $\mathrm{p}=0.003)$, maternal education $(\mathrm{b}=0.72, \mathrm{~S} . \mathrm{E}=0.28, \mathrm{p}=0.012)$, and history of infectious disease $(b=0.80 ; \mathrm{SE}=0.29 ; \mathrm{p}=0.007)$. History of infectious disease was affected by environmental sanitation $(b=0.31 ; \mathrm{SE}<0.001 ; \mathrm{p}<0.001)$, and family income $(b=0.25, \mathrm{SE}=0.05, \mathrm{p}<0.001)$. Dietary intake was affected by family income $(b=0.58, \mathrm{SE}=0.21, \mathrm{p}=0.007)$, history of infectious disease $(b=12.31 ; \mathrm{SE}=3.20 ; \mathrm{p}<0.001)$, and maternal education $(\mathrm{b}=7.39 ; \mathrm{SE}=3.09, \mathrm{p}=0.017)$. Maternal stress was affected by family income $(b=-0.16 ; \mathrm{SE}=0.06 ; \mathrm{p}=0.008)$.

Conclusion: Weight for age of children under five was directly affected by dietary intake, maternal education, and history of infectious disease. Weight for age of children under five was indirectly affected by environmental sanitation, family income, history of infectious disease, and maternal education.
\end{abstract}

Keywords: biopsychosocial, path analysis, environmental sanitation, nutritional status

\section{Correspondence:}

Wiwen Indita. Masters Program in Public Heath, Sebelas Maret University, Surakarta, Jl. Ir. Sutami 36 A, Surakarta 57126, Central Java. Email: wiwenindita29@gmail.com.

Mobile: +6282244970118.

\section{BACKGROUND}

Qualified human resources are a huge investment in the future. One of health problems that occur in Indonesia is problem on nutritional status, especially in nutrition-vulnerable age group: children under five years old. Children under five years old who suffers from long term chronic dietary intake will suffer from developmental disorders, immunity, and intelligence degradation (Lamid, 2012). In addition, the chronic dietary intake will increase the risk for morbidity and even mortality (Ogunrinade, 2014). If this situation persists within the next 20 years, then 
Indonesia will suffer from the lost generation (Hapsari, 2014).

Undernourishment is one of the terms of protein energy malnutrition diseases, namely the diseases that are caused by the lack of energy and protein intake. Children under five years old will be considered suffering from undernourishment if their Zscore according to W/A is between -3 to lower than -2 (Ministry of Health Indonesia RI, 2011).

Infection is a disease that 1-3 years old children suffer most of the time and one of the factors that cause infection is nutritional status among children under five years old (Putri et al., 2015). The infection-type diseases that most children under five years old suffer from are diarrhea, laryngitis, and acute respiratory system infection (Hidayat, 2011). A study by Baculu et al. (2016) concludes that children under five years old who suffer from infection-type disease have 2.38 times greater risk of sufffering from malnutrition. Children under five years old who suffer from infection-type diseases tend to easily suffer from undernourishment (Supraptini, 2011). A study by Rasyid et al. (2015) in the City of Ternate concluded that infectiontype disease such as pneumonia has been one of the causes behind nutrition-related problems and mortality cases among children under five years old. Based on data in Nganjuk District, in 2014 out of 63,430 children under five years old who were weighed it was obtained that pneumonia prevalence were equal to $3.46 \%$.

Another study by Alamsyah et al. (2015) concluded that children under five years old with poor sanitation have 5.03 times greater risk of sufffering from malnutrition and undernoursishment. This conclusion is in accordance to a study by Hidayat (2011), which concluded that unhealthy water will cause diarrhea and will decrease the weight; as a result, it will influence the nutritional status of children under five years old. An environment will be categorized as the healthy one if the water consumed is boiled water and the inhabitants do not keep their cattle around the house.

A study by Putri et al. (2015) concluded that children under five years old with poor nutritional status mostly come from the mothers with low educational level. The low educational level influences the level of the mother's understanding toward the nursery, the guidance, the provision of daily food for the children under five years old. This conclusion is in accordance to the results of a study by Saputra (2012) in the Province of West Sumatra, which concluded that children under five years old whose parents' educational background is low (elementary school graduate/dropout) has 5.70 times greater risk of sufffering from malnutrition. Then, the income level also contributes to an individual's capacity in affording the food according to the demanded level. A study by Persulessy et al. (2013) in Jayapura concluded that children under five years old whose parents' income has been low will have 4 times greater risk of suffering from malnutrition.

A study by Ejaz et al. (2012) concluded that the mother's mental health may influence the children's nutritional status. The mother's anxiety and mentall illness are associated to the low income within the family and as a consequence the mother's attitude in selecting the daily menu will be affect. The low income level will influence the food that will be consumed because the mother will not consider the nutrition values; instead, she will consider the economic values (Pratama, 2011). 
Journal of Epidemiology and Public Health (2017), 2(1): 32-44

https://doi.org/10.26911/jepublichealth.2017.02.01.04

Based on the results of WHO census in 2009 , there is $49.00 \% 10.4$ million children under five years old' mortality cases in the developing countries that have been related to the malnutrition (Hapsari, 2014). Initiating the Sustainable Development Goals (SDG's) 2016-2030, the government through the Plan of National MidTerm Development 2015-2019 has been determined to decrease the number of children under five years old with malnutrition and undernourishment until $17 \%$. In Indonesia, the prevalence of children under five years old with malnutrition and undernourishment has improved from $17.9 \%$ in 2010 into $19.6 \%$ in 2013 . The prevalence of malnutrition has improved from $4.9 \%$ into $5.7 \%$ (Balitbang Kemenkes RI 2013). The incident of malnutrition in the children under five years old from the Province of East java in 2014 has been 6,724 cases (0.3\%). Based on a survey on the cases of children under five years old with malnutrition in the Province of East Java on 2014, the Nganjuk District earned the $7^{\text {th }}$ place with the high number of malnutrition case. From the latest data in 2015 with regards to the prevalence of children under five years old with malnutrition, the researchers found that the prevalence has been $0.11 \%$.

\footnotetext{
SUBJECTS AND METHOD

\section{Design of the Study}

This study was an observational analytic research using retrospective cohort approach in which the exposition and the disease had already occurred in the past prior to the research administration; as a result, the variables in this study would be measured through historical notes (Murti, 2016). This study was conducted in Loceret Public Health Center and Tanjunganom Public Health Center from March to April 2017.
}

\section{Population and Sample}

The population in this study was all mothers and children under five years old in the region of Loceret Public Health Center and Tanjunganom Public Health Center. Then, the subjects in this study were 136 people. The sampling technique that the researchers employed was the fixed exposure sampling. According to Murti (2013), this technique had been useful in attaining sufficient number of research subject in the exposed and unexposed group.

\section{Variables}

The endogenous variables within this study were nutritional status in terms of Weight/ Age, nutrition intake, History of infectious disease, mother's psychological stress, and environmental sanitation. The exogeneous variables in this study were maternal educationand parents' income.

\section{Operational Definitions}

Nutritional status was operationally defined as the nutrition state of 12-60 month old children that had been assessed based on the index of weight for age using the Zscore table. Then, history of infectious disease was defined as the history of a child under five years old who suffered from the infection disease (diarrhea and pneumonia). Next, maternal psychological stress was defined as the psychological disorders that mothers experienced due to heavy burdens. Maternal education was the latest formal educational degree that mothers had.

Family income was the total income that parents earned. Environmental sanitation was the status of settlement condition that had been assessed in terms of clean water facilities, restroom availability, domestic sewage channel, and waste channel. Nutrition intake was the amount of nutrition that was consumed by the children under five years old, consisting of 
carbohydrate, protein, and fat intake measured based on the Recommended Daily Allowance and stated in percentage.

\section{Data Analysis}

Quantitative data were gathered using questionnaires, assessment form, and medical records. For the data analysis, the researcher employed the path analysis by using IBM SPSS AMOS 20. The steps in performing the data analysis by means of path analysis were as follows:

\section{a. Model specification}

Model specification depicted the relationship among the variables to be studied. The variables to be studied were categorized into the endogenous and the exogenous variables. The exogenous variables were the variables that would not be influenced by the other variables.

\section{b. Model identification}

Identification was conducted in the amount of measured variables, in the amount of endogenous variables, and in the parameters that would be estimated. In this stage, the researchers calculated the degree of freedom that indicated that path analysis might be performed.

Path analysis might be conducted if $\mathrm{df}$ $\geq 0$, if $\mathrm{df}=\mathrm{o}$ therefore path analysis model was considered "identified", whereas, if $\mathrm{df}>$ o then the path analysis model would be regarded as "over-identified" and if $\mathrm{df}<0$ then path analysis model would be regarded as "under-identified".

c. Model compatibility

The path analysis model that the researchers designed based on the theory was tested in terms of its compatibility to the best variable relationship model according to the software (SPSS Version 22). The best variable relationship model was known as the saturated model; this saturated model had been designed based on the sample data gathered by the researcher. If there was not any significant difference between both model then the model designed by the researcher was compatible with the data that reflected the reality of the inter-variable relationship.

The indicator that displayed the compatibility between the path analysis model designed by the researcher and the saturated model was as follows: chi square (CMIN) value had been small with $\mathrm{p} \geq$ 0.05; GFI, NFU, and CFI each was $\geq 0.90$; and RMSEA was $\leq 0.05$.

d. Parameter estimation

Causal relationship of the variables was presented by the regression coefficient (b), both the unstardadized one and the standardized one. The unstandardized regression coefficient displayed the relationship of dependent and independent variables in the original measurement units. On the other hand, the standardized regression coefficient calculated the standards of error for each variable so that the estimation size for the coefficient of regression from one independent variable to another might be compared in terms of its relative interest.

e. Model respecification

If the model made by researchers was not compatible with sample data as it was presented by saturation model and also if there was regression coefficient with too small value (nearly zero) in the saturated model, then the researcher should redesign the path analysis model in order to attain the model that would be fit into the sample data.

\begin{tabular}{l}
\hline RESULTS \\
The dimension of subject characteristics \\
was assessed according to the gender of \\
children, the age of children, the maternal \\
education, and the parents' income. Table 1 \\
displayed that from 136 subjects, 50.70\% \\
were female, $62.50 \%$ were less than 37 \\
months old, $74.30 \%$ were higher than \\
senior high school, and $41.90 \%$ were
\end{tabular}


parents whose income had been lower than the minimum regional wage while $58.10 \%$ were parents whose income had been equal or higher than minimum regional wage.

Table 1. Research subject characteristics

\begin{tabular}{llcc}
\hline Characteristics & \multicolumn{1}{c}{ Criteria } & n & \% \\
\hline Gender of children & Female & 69 & 50.7 \\
\multirow{3}{*}{ Age of children under five } & Male & 67 & 49.3 \\
& < 37 month old & 85 & 62.5 \\
Maternal education & $\geq 37$ month old & 51 & 37.5 \\
\multirow{2}{*}{ Family Income } & < Senior High School & 35 & 25.7 \\
& 2 Senior High School & 101 & 74.3 \\
& < IDR 1,411,000.00 & 57 & 41.9 \\
& $\geq$ IDR 1,411,000.00 & 79 & 58.1 \\
\hline
\end{tabular}

Table 2. Univariate analysis toward the study variables

\begin{tabular}{lccccc}
\hline \multicolumn{1}{c}{ Variables } & n & Mean & SD & Min. & Max. \\
\hline Materal psychological stress & 136 & 14 & 5.01 & 2 & 21 \\
Nutrition intake & 136 & 89 & 18.16 & 48 & 121 \\
Environmental sanitation & 136 & 1036 & 154.42 & 629 & 1261 \\
Family income & 136 & 16 & 6.71 & 5 & 35 \\
Nutritional status (WAZ) & 136 & -1.7 & 1.62 & -3.9 & 1.9 \\
Nutritional status (HAZ) & 136 & -1.2 & 1.77 & -3.8 & 4.4 \\
Nutritional status (WHZ) & 136 & -1.5 & 1.30 & -3.8 & 2.7 \\
\hline
\end{tabular}

Table 3. Bivariate analysis toward the influence of nutrition intake, history of infectious disease, maternal education, family income, and environmental sanitation to the children under five years old nutritional status (WAZ)

\begin{tabular}{lcc}
\hline Independent Variables & $\mathbf{r}$ & $\mathbf{p}$ \\
\hline Nutrition intake & 0.39 & $<0.001$ \\
History of infectious disease & 0.35 & $<0.001$ \\
Maternal education & 0.28 & 0.001 \\
Family income & 0.18 & 0.040 \\
Environmental sanitation & 0.25 & 0.003 \\
\hline
\end{tabular}

Table 3 displayed that nutrition intake $(\mathrm{r}=0.39, \mathrm{p}<0.001)$, history of infectious disease $(\mathrm{r}=0.35, \mathrm{p}<0.001)$, maternal education $(\mathrm{r}=0.28, \mathrm{p}=0.001)$, family income $(\mathrm{r}=$ $0.18, \mathrm{p}=0.040$ ), and environmental sanitation $(\mathrm{r}=0.25, \mathrm{p}=0.003)$ had positive influence and statistically significant toward the nutritional status (WAZ). Picture 1 showed the path analysis structural model of nutritional status (WAZ) children under five as the dependent variable after it had been estimated using the IBM SPSS AMOS 20; through this model the researchers attained the values that had been depicted above. The indicators that displayed the fitness of the analysis model in Table 4 displayed the presence of goodness of fit measure; from this measure, the researchers found that the fit index CMIN had been equal to 11.39 with $\mathrm{p}=0.36>0.05 ; \mathrm{NFI}=0.92 \geq 0.90 ; \mathrm{CFI} 0.99$ $\geq 0.95$; RMSEA $=0.02 \leq 0.08$. These results implied that the empirical model had met the already assigned criteria and had been declared fit into the empirical data. 


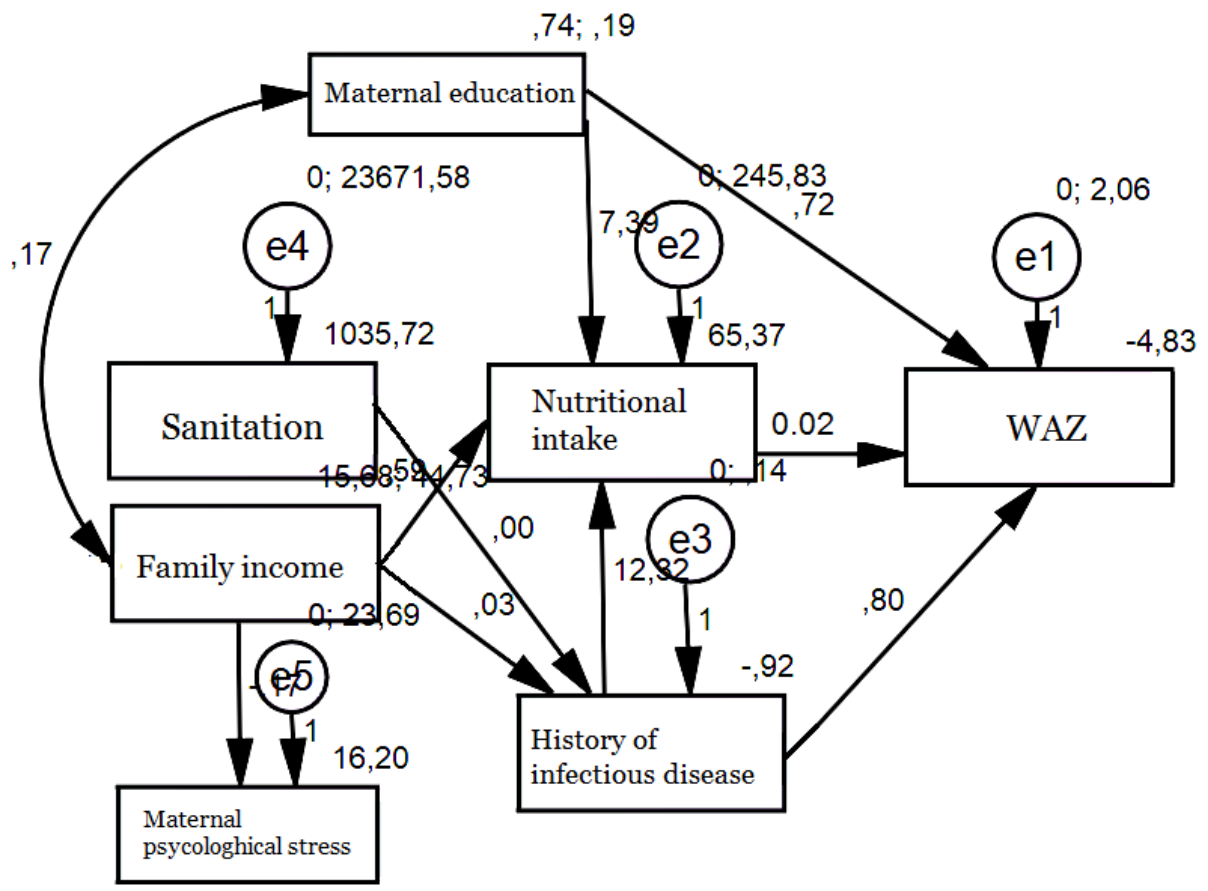

Picture 1. Path analysis structural model with estimation

Table 4. Results of path analysis

\begin{tabular}{|c|c|c|c|c|c|}
\hline Dependent Variables & Independent Variables & $\mathbf{b}^{*}$ & SE & $\mathbf{p}$ & $\beta^{* *}$ \\
\hline \multicolumn{6}{|l|}{ Direct Effect } \\
\hline \multirow[t]{3}{*}{ WAZ } & $\leftarrow$ Sufficient nutrition intake & 0.23 & 0.00 & 0.003 & 0.25 \\
\hline & $\leftarrow \begin{array}{l}\text { Maternal education } \geq \text { Senior High } \\
\text { School }\end{array}$ & 0.72 & 0.28 & 0.012 & 0.19 \\
\hline & $\leftarrow$ Not having infection disease & 0.80 & 0.29 & 0.007 & 0.22 \\
\hline \multicolumn{6}{|l|}{ Indirect Effect } \\
\hline \multirow{2}{*}{$\begin{array}{l}\text { History of infectious } \\
\text { disease }\end{array}$} & $\leftarrow$ Good environmental sanitation & 0.31 & 0.07 & $<0.001$ & 0.40 \\
\hline & $\leftarrow \quad$ Family income $(x$ Rp 100,000) & 0.25 & 0.05 & $<0.001$ & 0.37 \\
\hline \multirow{2}{*}{$\begin{array}{l}\text { Nutrition Intake } \\
\text { Nutrition Intake }\end{array}$} & $\leftarrow$ Family income $(x \mathrm{Rp} 100,000)$ & 0.58 & 0.21 & 0.007 & 0.22 \\
\hline & $\leftarrow$ Not having infection disease & 12.31 & 3.20 & $<0.001$ & 0.31 \\
\hline Nutrition Intake & $\leftarrow \begin{array}{l}\text { Maternal education } \geq \text { Senior High } \\
\text { School }\end{array}$ & $7 \cdot 39$ & 3.09 & 0.017 & 0.18 \\
\hline \multicolumn{2}{|l|}{ Psychological Stress } & -0.16 & 0.06 & 0.008 & $\begin{array}{c}- \\
0.22\end{array}$ \\
\hline \multicolumn{6}{|l|}{ Model Fit } \\
\hline \multirow{2}{*}{\multicolumn{6}{|c|}{$\begin{array}{ll}=2.57 & \mathrm{p}=0.463(>0.05) \\
=0.98 & (\geq 0.90)\end{array}$}} \\
\hline & & & & & \\
\hline$=1.00 \quad(\geq$ & \multicolumn{5}{|c|}{$(\geq 0.95)$} \\
\hline $\begin{array}{l}\text { RMSEA = o.oo } \quad(\leq \\
* \text { : unstandardized coe }\end{array}$ & $\begin{array}{l}\text { 8) } \\
\text { cient } \quad * * \text { : standardized coefficient }\end{array}$ & & & & \\
\hline
\end{tabular}

Through Table 4 the researchers found that the nutritional status (WAZ) was influenced by the nutrition intake, the History of infectious disease, and the maternal educational level.
Every 1-unit increase on the nutrition intake would increase the nutritional status (WAZ) by 0.23 unit $(b=0.23 ; \mathrm{SE}<0.001$; $\mathrm{p}=0.003)$. Every 1 unit increase on the maternal education $\geq$ Senior High School 
would increase the nutritional status (WAZ) by 0.72 unit $(b=0.72 ; \mathrm{SE}=0.28 ; \mathrm{p}=0.012)$.

The history of disease was influenced by the environmental sanitation and the family incomes. Then, the nutrition intake was influenced by the family income, the History of infectious disease, and maternal educational level. Maternal psychological stress was influenced by the family income.

Every 1-unit increase on the environmental sanitation would improve the health by 0.001 unit $(b=0.31 ;$ SE $<0.001 ; p$ $<0.001)$. Every 1-unit increase on the family income would increase the health by 0.025 unit $(b=0.025$; $\mathrm{SE}<0.001 ; \mathrm{p}<0.001)$. Every 1-unit increase on the family income would increase the health by 0.58 unit $(b=0.58$; $\mathrm{SE}=0.21 ; \mathrm{p}=0.007)$. Every 1-unit increase on the health would increase the nutrition intake by 12.31 unit $(\mathrm{b}=12.31 ; \mathrm{SE}=3.20 ; \mathrm{p}<$ 0.001). Every 1-unit increase on the maternal education $\geq$ Senior High School would increase the children under five nutritional status by 7.39 unit $(b=7.39$; $\mathrm{SE}=$ 3.09; $p=0.017$ ). Every 1-unit increase on the family income would decrease the maternal psychological stress by 0.16 unit $(b=-0.16$; $\mathrm{SE}=0.06 ; \mathrm{p}=0.008$ ).

\section{DISCUSSIONS}

\section{The influence of nutrition intake toward nutritional status of children under five years old (WAZ)}

There was a positive and statistically significant influence of nutrition intake toward nutritional status of children under five years old (WAZ). The nutrition intake is one of the factors that directly influence nutritional status of children under five years old. This finding is similar to that of a study by Terati et al. (2011), which concludes that the nutrition intake (energy and protein) has direct relationship to the nutritional status of children of 6-6o month old.
A study by Purwarningrum (2012) concludes that the children under five years old who obtain low nutrition intake has 2.872 times bigger opportunity to suffer from abnormal nutritional status compared to those who obtain sufficient nutrition intake. The similar type of food purchased in the same grocery on the same time will provide the same energy and protein value; as a result, it might be implied that the better nutrition intake, the more improving the nutritional status will be. On the contrary, the poorer the nutrition intake is, the worse the nutritional status will be.

A study by Baculu et al. (2015) concludes that children under five years old who had low energy intake has 9.86 times greater risk to suffer from undernourishment in comparison to those who have sufficient energy intake. The reason is that the amount of glucose from the diet is not available and the glycogen storage is also run out; as a result, the source of noncarbohydrate energy, namely lipid and protein, should be used. Lipid and protein will be transformed into the new glucose which then will endure catabolism in order to produce energy. Lipid and protein are used to produce energy and, therefore, it cannot perform it main function, as the result body metabolism is disturbed, and it leads to growth disorder.

This opinion is similar to the results of a study by Soumokil (2013) in the Province of Central Mollucas, which concludes that there is meaningful relationship between the energy intake and the protein intake with nutritional status based on weight/age index and weight/height index. The dietary pattern of most people in the Nusalaut Island involves local food (tubers and sago); as a consequence, the poor dietary habit and pattern will cause health problems and even malnutrition and undernourishment. The measurement of nutrition intake by using 
the 24 hours food recall method might display daily nutrition intake of children under five years old due to the different variability in the measurement days. The 24 hours food recall analysis consists of energy, protein, fat, and carbohydrate.

2. The influence of maternal education toward nutritional status of children under five years (WAZ)

There was positive influence of the maternal education toward nutritional status of children under five years old (WAZ) and statistically significant. The mothers with high educational level would be smart in selecting the nutritious food for their under five years old children. In this study, there were 35 mothers whose educational level was under Senior High School degree. The higher the maternal education is, the easier the mother will understand the nutritional information that they attain.

This finding is in accordance to that of a study by Saputra (2012) which concludes that parents with low educational level (elementary school graduate/dropout) have 5.699 greater risks to suffer from undernourishment in comparison to those with higher educational level. When the parents' educational level is low, their knowledge level toward nutrition and health will be low as well; as a result, the pattern of nutritional intake is poor also.

Maternal education is the main resource in supporting the family income because mother plays a vital role in arranging the food for the family and in upbringing the children. This opinion is in accordance to to the result of a study by Jannah (2014) which concludes that a mother has an important role in children's health and growth. This statement is evident in the fact that the children whose mothers have higher educational level will have better life opportunity, better development, and be easier to understand wider knowledge related to nutrition. On the other hand, the children whose mothers have lower educational background will have higher mortality rate compare to those whose mothers have higher educational background. The parents' role is heavily influential, especially for the mothers, because mothers play a significant role in the household management.

Grossman theory (1972) stated that education will influence the productivity and the effectiveness of health input so that people with higher educational background will be healthier than those who have lower educational background. This opinion is in line with the results of a study by Terati et al. (2011) which concluded that maternal education is related to nutritional status of children under five years old. Approximately $37.70 \%$ mothers with low educational background have under five years old children whose nutritional status is poor. A study by Putri et al. (2015) states that the low educational level will influence the level of understanding toward the children nurturing including in taking care the children, providing food, and guiding the children and this will lead to the more decreasing health and nutritional status.

The educational level may determine the individual's capacity in understanding and absorbing the knowledge that he or she has attained. The higher the educational level is, the better the knowledge will be. The parents' role, especially mothers', heavily influences the children under five years old.

\section{The influence of infectious disease history to nutritional status of children under five (WAZ)}

There was positive and statistically significant influence between the infection-type disease history and the nutritional status of children under five years old according to Weight/Age. Disease history is one of the factors that directly influence the nutritional 
status of children under five years old. The type of infectious disease in this study is diarrhea and pneumonia.

This finding is in accordance with $\mathrm{t}$ a study by Baculu et al. (2015) which concludes that there is significant relationship between the infectious disease history and the incidence of undernourishment among children under five years old $(\mathrm{p}<$ 0.05). The results of multivariate analysis showed that the children under five years old who suffer from the infectious disease has 2.83times greater chance to suffer from the undernourishment in comparison to those who did not have the infectious history.

The infectious isease that occurs repetitively or that is not handled immediately may cause children under five years old to lose their appetite, to suffer from nutrition malabsorption, and to have insufficient dietary intake.

According to the UNICEF Framework (1998), the nutritional status is influenced directly by the infectious diease. This opinion in accordance with the results of a study by Khayati (2011) which conclude that the infectious disease is related to the nutritional status of children under five years old among the farmer families in Banjarnegara. The infectious disease such as diarrhea and acute respiratory infection, is one of the mortality causes; however, the children under five years old who died because of the infectious disease are usually preceded by unsatisfying nutritional status. The more frequent the children under five years old suffer from the infectious disease, the higher the incidence of malnutrition and undernourishment figure among the children under five years old will be.

According to a study by Jayani (2014), the infection disease is heavily related to the low nutritional status. Body defense mechanism of the children under five years old who suffer from dietary intake insufficiency will decrease the body's capacity to produce new energy. This situation leads to the disorder on the establishment of body immune; as a result, the body becomes vulnerable to infection.

Isnaini (2016) concluded that children under five years old who suffer from infectious disease have 10 times greater risk to experience undernourishment in comparison to those who do not suffer from infection disease. Undernourishment and infectious disease have strong mutual relationship and nutrition disorder will decrease the children's capacity to deal with the infectious disease. The reaction toward the infectious disease is the decreasing appetite, which will lead to the decreasing nutritional status.

According to a study by Helmi (2013), the children under five years old with low nutritional status based on Weight/Age have 8.15 times greater risk to suffer from the infectious disease in comparison to the children under five years old who do not suffer from the infectious disease. Another impact from the infectious disease is the excessive use of energy to overcome the disease instead of for growth and development; as a result, the infectious disease may inhibit children's growth and development period. The infectious diseases that the most children under five years old suffer from are diarrhea, influenza, and cough. This might happen due to the unhealthy environment.

\section{The influence of environmental sanitation to nutritional status of children under five years (WAZ)}

There was indirect influence from the environmental sanitation to nutritional status of children under five years old (WAZ) through the history of infectious disease as the intervening variable. And it was positive and statistically significant. In this study, $32 \%$ unhealthy houses have children under 
five years old with low and poor nutritional status. According to the results of a study by Hidayat (2011), there is a statistically significant relationship between clean environmental sanitation and nutritional status of children under five years old (WAZ). This finding is also similar to the results of a study by Kusumanti (2014) which concluded that enviroment with poor sanitation will have negative impacts toward an individual's health. Numerous infectious diseases may occur since the environment with poor sanitation will be the breeding ground for multiple diseases.

According to a study by Abang (2012), there is significant relationship between environmental sanitation and infectious disease (acute respiratory infection, diarrhea) among children under five years old ( $p$ <0.05). Then, the infectious disease has significant relationship with nutritional status of children under five years old ( $\mathrm{p}<0.05$ ) in Tenggarong Sub-District, Kutai Kartanegara Regency. According to a study by Ningsih (2013), the cause of low (filthy, stinky) and moderate (dirty) environmental cleanliness is the disposal of organic and anorganic waste on the ditches in the front, the side, and the back part of the house; such disposal may cause the unpleasant odour. This conclusion is also in accordance with a study by Lidiawati (2016); that concludes that there is meaningful relationship between the provision of clean water, the use of toilet, and the waste disposal with the number of infectious disease (diarrhea) incidences among the children under five years old ( $\mathrm{p}<0.005)$.

The conclusion of this study is that the infectious diseases directly and significantly influence nutritional status of children under five years old (WAZ). Whereas the environmental sanitation has positive influence to the history of infectious disease of children under five years old; therefore, the environmental sanitation is the indirect influence to the nutritional status of children under five years old based on Weight/Age.

\section{The influence of family income to nutritional status of children under five (WAZ)}

There was indirect influence of the parents' income to the nutritional status of children under five years old (WAZ) through the history of infectious disease and the nutrition intake as the intervening variables. The influence of the parents' income to the history of infectious disease as well as to the nutrition intake was positive. Then, the inter-variables influence was statistically significant.

The number of research subjects whose income was under the minimum wage was 57 people; in other words, most of them have low income. Parents who have high income will be able to afford the sufficient dietary intake needs.

This opinion is in accordance to the results of a study by Saputra (2012) which concluded that poor people have greater risk to suffer from undernourishment and the chance to suffer from this undernourishment among the children under five years old alone has been 0.49. Then, there is an implication that the higher level of poverty and low level of education are the greatest risk in the case of undernourishment.

The results of a study by Pratama (2011) concluded that the lower the family income is, the worse the children under five years old' condition will be; on the contrary, the higher the family income is, the better the children under five years old' condition will be. The children under five years old in the family whose income is under the average have low nutritional status; their chance to suffer from malnutrition has been 2.82 times higher than the family whose income is above the average. Family income influences the level of daily dietary intake 
sufficiency. If a family has low income then the family members will not consider the nutrition value within the dietary intake; instead, they will only consider the economical value. The income level also influences what a family will purchase and consume.

The finding is similar to the opinion by Afriyani (2016) who concludes in her study that the factor that is related to the nutrition intake among the children under five years old in Palembang is the family's income level $(\mathrm{p}=0.017)$. Most people with low income level has been less able to meet the nutrition intake of their children under five years old because they only benefit the daily crops for meeting the daily nutrition intake.

According to a study by Sari (2012), the low family income will direct an individual to focus the earnings more on meeting the daily needs. As a consequence, the individual will not immediately meet a doctor if he or she suffers from certain disease. Only by the time that the disease has not been cured the individual will have medical checkup to the nearby medical staff. The infectious disease that is not immediately handled will impact nutritional status of children under five years (WAZ) indirectly due to low family income.

\section{The influence of the family income to the maternal psychological stress}

There was indirect influence from the family income to the maternal psychological stress. The influence is negative and statistically significant. The low family income will increase maternal psychological stress; as a result, the nutrition intake of children under five years old will be impacted and this will lead to the occurence of malnutrition and undernourishment among the children under five years old.

This opinion is in line with the results of a study by Ejaz et al. (2012) which concluded that maternal anxiety and depression are related to the low family income and this will influence the maternal behaviors in selecting the food for her children. Depression among women in developing countries is caused by the high social-economic pressures. The appropriate maternal attitudes and behaviors are important role in maintaining the healthy nutrition among the children under five years old.

According to a study by Diba et al. (2013), the symptoms of depression that a mother usually experiences include mood disorders in the form of sensitive feelings, sadness, loss of enthusiasm, fatigue, and poor bonding between her and her children. Depression symptoms that a mother experience will cause mother to have difficulties or disturbances in upbringing her children. Depression may also cause mother to have inadequate and less optimum attention in ensuring the food availability for meeting the children under five years old' nutrition intake.

The depression symptoms that a mother experiences will cause less optimal upbringing pattern, attitude and affection in supporting the children's development. The children may even suffer from psychological stress as well. The state of stress among the children will increase the production of amine. The increasing amine production will suppress the expression of neuropeptide $\mathrm{Y}$ (NPY) which is related to the children's appetite.

\section{REFERENCE}

Abang AT (2012). Hubungan Sanitasi Lingkungan dan Penyakit Infeksi dengan Status Gizi Anak Balita di Kecamatan Tenggarong Kabupaten Kutai Kartanegara. Yogyakarta: Program Studi Ilmu Kesehatan Masyarakat, Program Pascasarjana, Universitas Gadjah Mada. 
Afriyani R, Malahayati N, Hartati (2016). Faktor-Faktor yang Mempengaruhi Kejadian Wastin Pada Balita Usia 1-5 Tahun di Puskesmas Talang Betutu Kota Palembang. Jurnal Kesehatan. VII (1): 66-72

Alamsyah D, Mexitalia M, Margawati A (2015). Beberapa Faktor Risiko Gizi Kurang dan Gizi Buruk Pada Balita 1259 Bulan. Jurnal Vokasi Kesehatan. $1(5)$.

Baculu EPH, Juffrie M, Helmyati S (2015). Faktor Risiko Gizi Buruk Pada Balita di Kabupaten Donggala Provinsi Sulawesi Tengah. Jurnal Gizi dan Dietik Indonesia. 3 (1).

Balitbang Kemenkes RI (2013). Riset Kesehatan Dasar; RISKESDAS. Jakarta: Balitbang Kemenkes RI.

Depkes RI (2014). Profil Kesehatan Kabupaten Nganjuk 2014.

Ejaz MS, Sarwat A, Aisha T (2012). Maternal psychiatric morbidity and childhood malnutrition. Pak J Med Sci, 28 (5): 874-878.

Grossman M (1972). The Demand for Health: a Theoritical and Empirical Investigation. New York: National Bureau of Economic Research and Columbia University Press.

Hapsari D (2014). Waspadai Gizi Buruk Pada Balita. Jakarta: Tugu Publisher.

Helmi R (2013). Faktor-Faktor yang Berhubungan dengan Status Gizi Pada Balita di Wilayah Kerja Puskesmas Margototo Kecamatan Metro Kibang Kabupaten Lampung Timur. Jurnal Keseha$\tan$ IV (1): 233-242.

Hidayat TS, Fuada N (2011). Hubungan Sanitasi Lingkungan, Morbiditas dan Status Gizi Balita di Indonesia (Relationship Between Environmental Sanitation, Morbidity and Nutritional Status of Under-Five Children in In- donesia), Penel Gizi Makan, 34(2): 104-113.

Isnaini N (2016). Hubungan Pola Asuh, Pola Makan dan Penyakit Infeksi Dengan Kejadian Gizi Buruk Pada Balita Di Kabupaten Magetan Tahun 2016. Surakarta: Program Studi Ilmu Kesehatan Masyarakat, Universitas Muhammadiyah Surakarta.

Jannah M, Maesaroh S (2014). Hubungan Tingkat Pendidikan Ibu Dengan Status Gizi Balita Di Posyandu Bangunsari Semin Gunung Kidul.

Jayani I (2014). Hubungan Antara Penyakit Infeksi dengan Status Gizi pada Balita di Puskesmas Jambon Kecamatan Jambon Kabupaten Ponorogo Tahun 2014. Universitas Kadiri.

Kemenkes RI (2011). Keputusan Mentri Kesehatan Republik Indonesia Nomor 1995/MENKES/SK/XII/2010 tentang Standar Antropometri Penilaian Status Gizi Anak. Jakarta: Direktorat Jenderal Bina Gizi dan Kesehatan Ibu dan Anak Kementerian Kesehatan RI.

Kusumanti PD (2014). Hubungan Perilaku Personal Hygiene Ibu Dan Sanitasi Lingkungan Dengan Kejadian Diare Pada Balita Di Desa Karangsambung Kebumen Tahun 2014. Surakarta: Program Pascasarjana, Universitas Sebelas Maret.

Khayati S (2010). Faktor yang Berhubungan dengan Status Gizi Balita pada Keluarga Buruh Tani di Desa Situwangi Kecamatan Rakit Kabupaten Banjarnegara Tahun 2010. Semarang: UNNES.

Lamid A, Irawati A, Amelia (2012). Penanganan Balita Gizi Buruk Secara Rawat Jalan di Puskesmas dengan Pemberian Makanan Terapi: Formula-10o dan Ready to Use Therapeutic Food. Penel Gizi Makan, 35(2): 168-181.

Lidiawati M (2016). Hubungan Sanitasi Lingkungan Dengan Angka Kejadian 
Diare Pada Balita Di Wilayah Kerja Puskesmas Meuraxa Tahun 2016. Serambi Saintia, IV(2).

Murti B (2013). Desain dan Ukuran Sampel untuk Penelitian Kuantitatif dan Kualitatif di Bidang Kesehatan. Yogyakarta: Gadjah Mada University Press.

Murti B (2016). Prinsip dan Metode Riset Epidemiologi. Surakarta: Pascasarjana Kesehatan Masyarakat, Universitas Sebelas Maret.

Ningsih ID (2013). Hubungan Kesehatan Lingkungan Terhadap Status Gizi Anak Prasekolah di Kelurahan Semanggi dan Sangkrah. Kecamatan Pasar Kliwon Surakarta. Surakarta: Program Studi Ilmu Kesehatan Masyarakat, Universitas Muhammadiyah Surakarta.

Ogunrinade SA (2014). The Incidence of Malnutrition in Children (Age $\mathrm{O}-5$ Yrs). Journal of Agriculture and Life Sciences, 1(2).

Persulessy V, Mursyid A, Wijanarka A (2013). Tingkat pendapatan dan pola makan berhubungan dengan status gizi balita di Daerah Nelayan Distrik Jayapura Utara Kota Jayapura. Jurnal Gizi dan Dietik Indonesia, 1(3): 143150.

Pratama AR (2011). Pengaruh Tingkat Pendidikan, Tingkat Pendapatan, Pengetahuan Ibu, Sikap Ibu dan Perilaku Ibu Terhadap Status Gizi Balita di Kecamatan Kesamben Kabupaten Jombang. http://ejournal.unesa.ac. id. Diakses 11 Desember 2016.

Putri RF, Sulastri D, Lestari Y (2015). Faktor-Faktor yang Berhubungan dengan Status Gizi Anak Balita di Wilayah Kerja Puskesmas Nanggalo Padang. Jurnal Kesehatan Andalas, 4(1).

Purwaningrum S, Wardani Y (2016). Hubungan antara Asupan Makanan dan Sta- tus Kesadaran Gizi Keluarga dengan Status Gizi Balita di Wilayah Kerja Puskesmas Sewon I, Bantul. Jurnal Kesmas UAD, 6 (3).

Rasyid R, Mayulu N, Kandou GD (2015). Hubungan Karakteristik Balita, Penyakit Infeksi dengan Status Gizi pada Anak Balita di Wilayah Kerja Puskesmas Gambesi Kota Ternate. Universitas Sam Ratulangi.

Saputra M (2012). Hubungan Antara Riwayat Bayi Berat Lahir Rendah (BBLR) dengan Status Gizi Pada Anak Balita di Kelurahan Pringgokusuman, Kecamatan Gedongtengen, Kota Yogyakarta. Surakarta: Universitas Muhammadiyah.

Soumokil O (2013). Hubungan Pola Makan dan Asupan Zat Gizi dengan Status Gizi Anak Balita di Pulau Nusalaut Kabupaten Maluku Tengah. Yogyakarta: Universitas Gadjah Mada.

Supraptini, Hapsari D (2011). Status Gizi Balita Berdasarkan Kondisi Lingkungan dan Status Ekonomi (Data Riskesdas 2007). Jurnal Ekologi Kesehatan, 10(2): 103-113.

Terati, Nilawati NS, Fatonah RS (2011). Faktor-Faktor yang Berhubungan dengan Status Gizi Balita Usia 06-6o Bulan di Kelurahan Kuto Batu Kecamatan Ilir Timur Ii Kota Palembang Tahun 2011. http://jurnal.poltekkespalembang.ac.id.

UNICEF (1998). The State of The World's Children. Oxford University press. 